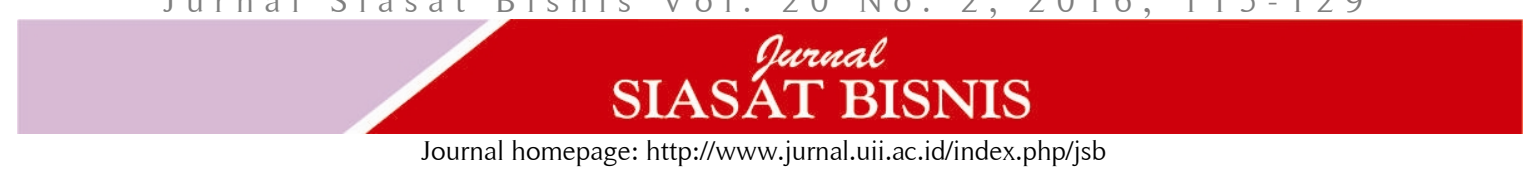

\title{
Kepemilikan Aset Spesifik, Keunggulan Kompetitif, dan Struktur Modal Perusahaan: Studi Kasus Perusahaan Publik di Indonesia
}

\author{
Buddi Wibowo \\ Program Studi Pascasarjana Ilmu Manajemen \\ Fakultas Ekonomi dan Bisnis Universitas Indonesia \\ e-mail: buddi.wibowo@ui.ac.id
}

\begin{abstract}
Sustainable competitive advantage arises from unique asset ownership. Asset specificity creates company's distinctive competence that difficult to be imitated by competitor. This asset specificity is more difficult to imitate if information and description about this asset are not transparent for competitor, even for company that owns this asset because of the unique production process or ambiguous relationship with other internal factors such as corporate culture and quality of human resources. On the other hand, the ownerhip of this specific and opaque asset has serious consequences on financing strategy. Bank faces serious difficulty to make an accurate valuation of specific and opaque asset so that bank charges higher cost of debt. This will imply that company capital structure will be dominated by equity. This paper test this hypothesis in Indonesian context using non-financial firm data. This paper tests empirically hypothesis that is developed from resource based view strategy that very well known in strategic management literature stating that the asset specificity and opacity affect financial strategy of the firm. We found that Indonesian firms have unique condition that different from expectation of resource based view strategy. On average, Indonesian firms' $R \& D$ expenses are very low and have very marginal effect to capital structure. Conservatism of Indonesia accounting principle on reporting $R \& D$ expenses has serious bias on measuring asset specificity and opacity.
\end{abstract}

Keywords: asset specificity; opacity; capital structure; distinctive competence

\begin{abstract}
Abstrak
Sustainable competitive advantage muncul dari kepemilikan asset-asset yang memiliki suatu keunikan sehingga menciptakan distinctive competence yang sulit ditiru oleh para pesaing. Keunikan tersebut makin sulit ditiru apabila asset tersebut tidak transparan bagi para pesaing atau, bahkan, bagi perusahaan yang memilikinya sendiri karena proses produksi yang unik atau ambiguitas hubungannya dengan faktor-faktor internal lainnya seperti kultur perusahaan atau kualitas SDM. Namun di sisi lain, kepemilikan asset yang unik ini membawa dampak yang serius bagi perusahaan dari sisi pendanaannya. Bank, misalnya, kesulitan untuk menilai secara akurat asset yang spesifik dan opaque seperti ini sehingga biaya hutang yang dituntut bank menjadi lebih tinggi. Implikasi dari hal itu, struktur modal perusahaan seperti ini akan didominasi oleh ekuitas. Riset ini berupaya menguji hal tersebut dalam konteks perusahaan-perusahaan non keuangan di Indonesia sekaligus uji empirik atas hipotesis resource based strategy yang dikenal dalam literature manajemen strategik dengan riset empirik keuangan yang sejauh ini tidak mempertimbangkan komposisi dan keunikan asset dapat mempengaruhi struktur modal perusahaan. Kami menemukan bukti bahwa perusahaan Indonesia memiliki kondisi yang berbeda dari yang diprediksi oleh resouce based view strategy. Pengeluaran R\&D rata-rata perusahaan Indonesia relatif sangat rendah dan tidak berdampak pada struktur modal perusahaan. Selain itu, konservatif nya prinsip akuntansi Indonesia diduga menciptakan bias pengukuran asset spesifik dan asset opacity.
\end{abstract}

Kata Kunci: spesifitas aset; opasitas; struktur modal; dan kompetensi distingtif

JEL: G10, G30, G31, G32

DOI: 10.20885/jsb.vol20.iss2.art2 


\section{Pendahuluan}

Dalam bidang manajemen strategik dikenal ada dua pandangan bagaimana seharusnya strategi perusahaan disusun, pertama adalah market-based strategy dan kedua adalah resources-based strategy (Shou et al, 2013;Grant, 1991). Menurut pandangan market-based, strategi perusahaan diarahkan oleh dinamika pasar produknya masing-masing. Persaingan dan perubahan selera konsumen menjadi faktor-faktor yang perlu selalu diawasi perusahaan ketika menyusun kembali strategi. Orientasi strategi lebih pada antisipasi dan memanfaatkan peluang pasar. Sementara menurut pandangan resources-based, perusahaan seharusnya fokus pada membangun sumber daya internal perusahaan sehingga dapat diperoleh suatu kompetensi yang nyata (distinctive competence). Perubahan lingkungan eksternal perusahaan dapat selalu diatasi apabila perusahaan memiliki kompetensi yang nyata dan riil (Agha et al, 2012).

Aset yang unik dan spesifik menjadi dasar terciptanya distinctive competence sebuah perusahaan (De Vita, et al. 2011). Asset yang memberikan kekuatan spesifik bagi perusahaan dengan sendirinya harus memenuhi karakteristik yang unik sehingga sulit ditiru oleh kompetitor. Kompetitor tidak dapat dengan mudah mendapatkan asset tersebut di pasar karena asset tersebut non-tradable dan sangat spesifik. Namun justru karena memiliki karakter seperti itu muncul biaya yang besar untuk memperoleh dan mempertahankan asset seperti itu (Mingyue, 2011).

Keunikan suatu asset dapat berupa karakteristik khusus asset tersebut, proses produksi tertentu yang melibatkan asset itu, terbatasnya supply atau faktor-faktor pendukung operasional asset seperti dalam bentuk keterampilan dan budaya kerja SDM ( ). Namun keunikan itu tidak akan bertahan lama apabila informasi atas asset tersebut dapat dimiliki oleh perusahaan lain dengan relatif mudah. Dimensi ketidakjelasan (opacity) harus ada pada asset yang unik sehingga nilainya bagi perusahaan tetap tinggi (Mingyue, 2011). Opaque asset adalah suatu asset yang secara alamiah atau karena upaya khusus perusahaan yang memilikinya sedemikan rupa menyebabkan upaya imitasi menjadi sulit karena informasi yang berkaitan dengan asset tersebut tidak dapat diperoleh oleh pihak lain di luar perusahaan. Informasi ini dapat berupa cara memperoleh suatu strategic resource atau kapabilitas tertentu, cara mengakumulasinya dan memanfaatkannya dalam suatu proses produksi, atau dapat pula dalam bentuk sulitnya memprediksi expected value dari penggunaan asset itu sehingga sulit untuk menentukan nilainya. Biaya untuk memperolehnya, seperti yang dinyatakan oleh De Vita, et al. (2011), juga tidak dapat dikalkulasi karena tidak kasat mata (unobservable).

Bagi perusahaan yang sudah memiliki distinctive asset, operasi asset spesifik menimbulkan masalah lanjutan yaitu tingginya biaya implementasi, penguatan dan pembangunan agar asset tersebut terus dapat menciptakan keunggulan kompetitif dalam jangka panjang. Oleh karenanya menurut (Lee-Hsien et al, 2015;Vilasuso dan Minkler, 2001) strategi level korporat seperti ini akan berpengaruh langsung terhadap strategi level fungsional keuangan yaitu strategi pendanaannya. Strategi pendanaan untuk memperoleh asset yang unik berbeda dengan pendanaan atas asset yang lainnya (Vicente-Lorente, 2001;). Harga pasar asset spesifik yang tidak dapat diketahui secara pasti membuat recovery rate dari asset tersebut apabila asset tersebut harus dilikuidasi menjadi sangat rendah (Benmelech, 2009). Rendahnya recovery rate dan sulitnya untuk mengkalkulasi nilai asset yang spesifik menyebabkan pembiayaan asset spesifik menjadi sangat berisiko dan akan dihindari oleh bank (James dan Kizilaslan, 2014). Pendanaan asset spesifik dapat diduga lebih banyak menggunakan instrumen saham (Williamson, 2010).

Apabila Williamson (2010) menduga pendanaan asset spesifik cenderung menggunakan saham, De Vita, et al (2011) membangun rerangka pikir yang berbeda. Menurut De Vita, et al (2011), asset yang spesifik memiliki ciri yang khusus yaitu kerahasiaan yang tinggi atas karakteristiknya, proses operasi, dan hubungannya dengan faktor-faktor internal perusahaan yang sangat spesial. Kerahasiaan tersebut harus dijaga agar keunggulan bersaing yang didasarkan pada asset tersebut dapat sustainable. Dengan rerangka logik seperti ini, pendanaan 
asset yang spesifik justru cenderung menggunakan pendanaan internal, jika pendanaan internal tidak mencukupi baru lah menggunakan sumber pendanaan eksternal baik dalam instrumen hutang maupun saham. Karena instrumen hutang relatif lebih longgar governance structure nya dibandingkan saham, urutan penggunaan pendanaan eksternal dimulai dari hutang baru menggunakan saham. Pola pendanaan seperti ini sesuai dengan pecking order theory. Pecking order theory menyatakan struktur modal perusahaan disusun secara berurutan disesuaikan dengan tingkat ketersediaannya yaitu dari pembiayaan internal, lalu dengan instrumen hutang berisiko rendah dan akhirnya ekuitas sebagai pilihan terakhir.

Riset yang menguji secara empirik hubungan strategi pendanaan dan keunikan asset perusahaan masih relatif minim (Chakraborty, 2010; Vicente-Lorente, 2001) karena merupakan pertemuan dari dua bidang riset yaitu manajemen strategi dan keuangan dimana kedua bidang itu memiliki rerangka pikir yang jauh berbeda. Henard dan McFadyen, 2012 dan De Vita, et al (2011) menunjukkan bahwa umumnya riset manajemen strategik fokus pada paradigma strategi dan proses penyusunan strategi perusahaan sebagai antisipasi perubahan lingkungan eksternal seperti persaingan, perubahan selera konsumen yang efeknya terhadap strategi produk dan harga yang harus selalu direvisi. Bagaimana strategi level korporat ini mempengaruhi strategi pendanaan yang merupakan strategi level fungsional keuangan belum diriset secara mendalam. Sementara riset keuangan umumnya didasarkan kepada teori struktur modal klasik yang tidak mempertimbangkan karakteristik asset yang dimiliki perusahaan sebagai determinan kebijakan pendanaan.

Determinan struktur modal perusahaan Indonesia yang akan diteliti juga dalam penelitian ini adalah BUMN dan grup usaha. BUMN tidak memiliki pemegang saham yang "real" karena pemerintah sebagai pemegang saham dan diwakili oleh para komisaris sering kali mengambil keputusan bukan didasari oleh orientasi maksimisasi shareholder value melainkan demi kepentingan politis atau kepentingan pembangunan secara keseluruhan.

Faktor lain yang patut di duga mempengaruhi struktur modal perusahaan di Indonesia adalah apakah perusahaan bergabung dalam sebuah grup usaha atau konglomerasi tertentu. Chakraborty (2013) membuktikan bahwa strategi pendanaan perusahaan yang tergabung dalam sebuah konglomerasi berbeda dengan perusahaan yang stand alone. Konglomerasi memiliki strategi besar sebuah grup usaha yang menempatkan masing-masing perusahaan yang bergabung dalam konglomerasi tersebut pada posisi tertentu, misalnya cash cow atau rising star, dalam menjalankan strategi besar konglomerasi itu. Posisi setiap perusahaan di dalam portofolio bisnis yang dimiliki konglomerasi menentukan strategi pendanaan perusahaan tersebut. Perusahaan yang sahamnya tercatat di bursa efek Indonesia banyak didominasi oleh konglomerasi.

Uji empirik hubungan antara kepemilikan asset spesifik, yang salah satu proxy nya adalah rasio biaya $R \& D$ dan total biaya, pada konteks perusahaan Indonesia menjadi menarik karena pengeluaran R\&D Indonesia secara total dibandingkan dengan Produk Domestik Bruto (GDP) relatif jauh lebih rendah dibandingkan negara-negara lain. Uji pada perusahaanperusahaan India, yang pengeluaran R\&D nya juga termasuk rendah yang dilakukan oleh Chakraborty (2010) membuktikan adanya hubungan signifikan negatif antara biaya R\&D dengan leverage perusahaan. Pengeluaran R\&D perusahaan India terindikasi menciptakan keunikan asset sehingga mendorong penggunaan sumber pendanaan lain di luar hutang bank. Pengeluaran R\&D Indonesia lebih rendah sepersepuluh dari India dan hanya lebih tinggi dari negara seperti Trinidad Tobago dan Bahrain. (Lihat Tabel 1)

Penelitian ini bertujuan untuk menguji secara empirik hubungan antara strategi bersaing perusahaan melalui penciptaan dan kepemilikan asset yang spesifik dengan struktur modal perusahaan yang mencerminkan pola pendanaannya. Untuk mempertajam hasil uji, selain karakteristik BUMN dan grup usaha, faktor-faktor lain yang mempengaruhi struktur modal perusahaan seperti probabilita kebangkrutan (Baghai, et al 2014), Non Debt Tax Shield (Chakraborty, 2010;Blouin, et al, 2010), profitabilitas (Fan, et al, 2012) dan growth option 
(Williamson, 2010) dimasukkan pula ke dalam model. Model estimasi yang digunakan dalam penelitian ini adalah General Method of Moment (GMM) yang diperlukan untuk memperoleh hasil estimasi koefisien yang tidak bias dan efisien (Wooldridge, 2012;Chakraborty, 2010)

Tabel 1. Perbandingan Pengeluaran R\&D terhadap GDP Antar Negara

\begin{tabular}{lc}
\hline \multicolumn{1}{c}{ Negara } & \% Pengeluaran R\&D terhadap GDP \\
\hline Israel & 4.2132 \\
Korea Selatan & 4.1485 \\
Jepang & 3.4740 \\
Jerman & 2.8534 \\
Amerika Serikat & 2.8060 \\
China & 2.0146 \\
Singapura & 1.9994 \\
Malaysia & 1.1266 \\
India & 0.8222 \\
Thailand & 0.3877 \\
Indonesia & 0.0848 \\
Trinidad Tobago & 0.0485 \\
Bahrain & 0.0419 \\
\hline Sumber: Wordd Developmt
\end{tabular}

Sumber: World Development Indicator, World Bank, 2015

\section{Tinjauan Teoritis}

Asset specificity adalah konsep yang muncul dari transaction cost theory yang menjadi rerangka teoretis yang dominan dalam studi organizational boundary choices (Khare dan Leiblein, 2014). Asset specificity adalah karakteritik yang unik dari sebuah asset yang menciptakan keuanggulan bersaing bagi perusahaan yang memilikinya (De Vita, et al, 2011). AAsset specificity bersifat multi aspek yang berarti spesifiknya suatu asset merupakan kombinasi dari empat sumber yang menyebabkan suatu asset menjadi unik yaitu spesifik secara fisik, prosedur operasi, tempat dan, SDM pendukung.

Memahami hubungan antara karakteristik asset dengan struktur modal perusahaan menjadi rumit karena bagaimana mengukur seberapa unik asset sebuah perusahaan masih menjadi perdebatan di kalangan para peneliti. De Vita, et al, (2011) menggunakan fixed-to-total assets, James dan Kizilaslan (2014) menggunakan asset recovery rate, dan Lee-Hsien, et al (2015) menggunakan market-to-book assets ratio. Ada beberapa kritik terhadap metode pengukuran tersebut (Khare dan Leiblein, 2014). Fixed-to-total assets lebih tepat mengukur struktur biaya tetap perusahaan dan tingkat otomatisasi, bukan keunikan asset. Asset recovery rate hanya diketahui untuk perusahaan yang telah dilikuidasi. Market-to-book assets ratio merupakan proxy atas peluang pertumbuhan perusahaan di mata investor bursa saham. Mingyue (2011) dan Khare dan Leiblein (2014) menggunakan biaya R\&D dan biaya pemasaran yang intensitasnya dapat dilihat sebagai indikasi adanya akumulasi dan penciptaan asset yang spesifik. De Vita, et al (2011) membuktikan bahwa alasan utama perusahaan teknologi tinggi untuk membangun secara internal karena asset tersebut spesifik dan memilih in-house production untuk beberapa aktivitas utama sebagai respons atas ancaman pemanfaatan informasi tersebut oleh kompetitor. Proteksi atas ancaman tersebut kemudian diikuti dengan pengurusan patent atau prosedur kerahasiaan internal perusahaan.

Investasi dalam bentuk human capital merupakan salah satu petunjuk seberapa tinggi tingkat keunikan dan kerahasiaan asset perusahaan. Beberapa peneliti seperti (Shou, et al, 2013 dan Mingyue, 2011) menggunakan ukuran rata-rata lama masa kerja dan employee turnover, namun ukuran ini sulit diperoleh datanya. Menurut De Vita, et al. (2011), apabila seorang pegawai tertentu dibutuhkan untuk mengoperasikan asset yang spesifik maka perusahaan 
terlebih dahulu perlu investasi dalam bentuk program training dan coaching internal yang sangat tailor made. Biaya pelatihan dan coaching yang tinggi kemudian akan diikuti dengan biaya gaji yang relatif tinggi pula untuk menjaga loyalitas pegawai terhadap perusahaan dan mengurangi kemungkinan bocornya informasi internal perusahaan kepada kompetitor. Semakin tinggi biaya pelatihan dan coaching yang telah dikeluarkan perusahaan, sehingga dapat disebut sebagai sunk cost, semakin besar gaji pegawai yang perusahaan bersedia keluarkan.

Investasi perusahaan dalam sumber daya yang spesifik dan tidak transparan (opaque) akan berhubungan negative dengan debt ratio perusahaan karena perusahaan tersebut harus menanggung cost of debt yang lebih tinggi (Vilasuso dan Minkler, 2001). Keunikan asset membuatnya menjadi lebih berisiko di mata bank. Selain itu kapasitas pinjaman dari asset yang opaque juga terbatas karena recovery rate yang rendah (James dan Kizilaslan, 2014). Perusahaan yang memiliki asset yang spesifik akan memiliki rasio hutang yang rendah. Hal ini konsisten dengan hasil uji empirik sebelum ini yang menunjukkan hubungan positif antara asset spesifik dengan financial leverage (Vilasuso dan Minkler, 2001).

Setelah melakukan survey sejumlah besar riset empirik atas struktur capital perusahaanperusahaan di Amerika Serikat, Fan, et al (2012) dan Chakraborty (2010) untuk data perusahaanperusahaan India, menyimpulkan bahwa leverage meningkat dengan semakin besarnya asset tetap, non debt tax shields, dan ukuran perusahaan, dan cenderung menurun dengan semakin besarnya peluang investasi, biaya pemasaran, probabilita kemungkinan bangkrut, profitabilitas, dan keunikan produk. Hasil uji empirik Fan, et al (2012) dan Chakraborty (2010) ini mendukung beberapa kerangka teoretis. Misalnya besarnya asset tetap yang dapat berfungsi sebagai kolateral hutang menyebabkan rendahnya agency costs of debt dimana pemberi hutang dapat lebih terlindungi dari keputusan manajer dan pemegang saham yang berisiko. Peluang pertumbuhan yang direpresentasikan jumlah asset tidak berwujud berhubungan terbalik dengan jumlah hutang perusahaan. Hutang perusahaan berhubungan terbalik dengan bankruptcy costs (yang ditunjukkan oleh cash flows volatility dan default probability). Hubungan terbalik antara tingkat profitabilitas dan rasio hutang membuktikan kesesuaian teori pecking order theory dengan realitas, dimana pola pendanaan dipengaruhi oleh adanya information asymmetries antara potential lenders dan manajer (Lee-Hsien, et al. 2015).

Leverage perusahaan sangat dipengaruhi oleh peluang industri dan perusahaan itu sendiri untuk terus tumbuh. Semakin besar peluang pertumbuhan karena perubahan industri dan selera konsumen yang dinamis, semakin besar kebutuhan dana untuk investasi supaya perusahaan dapat mempertahankan pangsa pasarnya. Semakin besar peluang pertumbuhan perusahaan, perbankan semakin mudah menyalurkan kredit dengan biaya bunga yang lebih rendah dan mempengaruhi secara langsung keputusan struktur modal perusahaan. Kemungkinan pertumbuhan perusahaan sering disebut sebagai growth option. Beberapa peneliti menggunakan ukuran yang berbeda untuk growth option, misalnya Rajan dan Zingales (1995) mengukur growth options dengan menggunakan market-to-book equity ratio yaitu rasio antara harga saham perusahaan di bursa saham dengan nilai buku ekuitas yang tercatat di laporan keuangan perusahaan. Williamson, (2010) menggunakan pertumbuhan penjualan, Vilasuso dan MInkler (2001) menggunakan variasi rasio investasi pada asset tetap, dan Vicente-Lorente (2001) menggunakan rasio net capital investment expenditure terhadap total assets.

Leverage dipengaruhi juga oleh ketersediaan pendanaan internal perusahaan. Transaksitransaksi non kas yang harus tercatat dalam laporan laba rugi perusahaan namun pada hakikatnya tidak terdapat aliran uang keluar merupakan salah satu indikator dana internal perusahaan. Biaya depresiasi, amortisasi dan non cash transaction lainnya memberi ruang bagi perusahaan untuk mengurangi jumlah hutangnya tanpa harus menurunkan kapasitas produksinya. Hal ini lah yang memunculkan hipotesis adanya hubungan negatif antara non debt tax shield dengan financial leverage (Chakraborty, 2010; Blouin, et al, 2010). Uji empirik menunjukkan hasil yang belum konvergen dan bahkan bertentangan dengan hipotesis tersebut 
karena metode pengukuran atas non debt tax shield yang berbeda-beda. Besarnya nilai depresiasi tidak sepenuhnya dapat menangkap besaran tax shields namun lebih pada dimensinya sebagai kolateral hutang karena mencerminkan besarnya asset tetap yang dimiliki oleh perusahaan. (Blouin, et al, 2010) mengusulkan alat ukur alternatif terhadap non-debt tax shields (NDT) yang relative lebih mudah dihitung tapi memiliki akurasi yang cukup baik.

Variabel lain yang mempengarungi tingkat leverage perusahaan adalah probabilita kebangkrutan perusahaan. Beberapa peneliti sebelum ini membuktikan adanya hubungan terbalik antara tingkat leverage perusahaan dengan probabilita bangkrut (Baghai, et al , 2014; Fan et al, 2012). Semakin tinggi probabilita default akan menyebabkan rating perusahaan semakin buruk sehingga tingkat suku bunga yang dituntut bank atau pemegang obligasi akan semakin tinggi. Semakin besar probability default, semakin kecil leverage perusahaan.

Pengukuran probabilitas kebangkrutan perusahaan menjadi masalah riset tersendiri (Ciliberto dan Schenone, 2012; Altman dan Sabato, 2007). Ukuran yang muncul paling awal adalah dengan model analisis multidiskriminan seperti yang dibangun oleh Altman yang menghasilkan ukuran Altman Z -score. Altman's Z-score tidak dapat digunakan sebagai alat ukur probabilita kebangkrutan. Altman Z-score hanya dapat digunakan sebagai indikator perusahaan akan menderita kesulitan keuangan (Grice dan Ingram, 2001). Penggunaan model diskriminan dengan model Altman akan menderita bias yang cukup besar apabila model tersebut diestimasi dengan menggunakan data yang berbeda (Platt dan Platt, 2002). Model Altman Z score akan memiliki besaran koefisien yang berbeda pada konteks perusahaan Indonesia. Menggunakan model Altman Z score hasil estimasi dengan data Amerika Serikat untuk memprediksi peluang bangkrut perusahaan Indonesia dapat menghasilkan prediksi yang keliru.

Perusahaan BUMN sebagai perusahaan negara memiliki karakteristik khusus dalam penentuan keputusan struktur modalnya karena governance yang berbeda dengan perusahaan lain (Mingyue, 2011). Dukungan pemerintah dalam bentuk finansial menjadi faktor penting agar perusahaan BUMN tidak mengalami kesulitan keuangan. Bentuk dukungan finansial yang paling sering adalah penempatan dana pemerintah sebagai modal perusahaan. Bentuk dukungan finansial lainnya dapat berupa jaminan proyek oleh pemerintah, dana pendampingan dari pemerintah, atau pemerintah menghubungkan perusahaan dengan sumber-sumber pendanaan yang memberikan biaya dana yang lebih murah seperti dana dari lembaga-lembaga keuangan internasional yang memang bertujuan untuk mendorong pembangunan di negara-negara anggotanya (Mingyue, 2011)

Perusahaan yang tergabung dalam sebuah konglomerasi memiliki strategi pendanaan yang khas dibandingkan dengan perusahaan yang berdiri sendiri (Chakraborty, 2013). Konglomerasi menempatkan semua perusahaan yang berada di dalam grup usahanya dalam sebuah portfolio usaha yang saling sinergi dalam menjalankan strategi konglomerasi secara bersamaan. Apabila di dalam konglomerasi ada perusahaan lain yang berada pada tahap introduction, prioritas pendanaan lebih didahulukan pada perusahaan yang berada di tahap introduction dari pada perusahaan yang berada di tahap growth karena mencari pendanaan eksternal untuk perusahaan pada tahap introduction relatif lebih sulit karena prospek pasar sering kali belum jelas (Du dan Girma, 2012).

\section{Metode Penelitian}

Data yang digunakan adalah seluruh perusahaan terbuka di luar perusahaan industri keuangan yang tercatat di Bursa Efek Indonesia sejak tahun 2000 sampai 2013 dan memiliki laporan keuangan yang lengkap yang menampilkan seluruh data untuk semua variable yang dibutuhkan dalam penelitian ini. Perusahaan yang berada di industri keuangan seperti bank, asuransi, perusahaan multifinance dan perusahaan sekuritas dikeluarkan dari sample karena memiliki format laporan keuangan yang berbeda dengan perusahaan non keuangan. Selain itu perusahaan yang berada di industri keuangan diregulasi penuh oleh regulator baik dalam hal pembukaan 
cabang bank sampai jumlah dana yang harus dikeluarkan dalam bentuk pelatihan pegawai. Karakteristik khusus dari lembaga keuangan tersebut membuat perusahaan-perusahaan keuangan tidak dapat dibandingkan secara langsung dengan perusahaan dari industri yang lain. Jumlah perusahaan yang menjadi sample adalah 169 perusahaan.

\section{Variabel dan Pengukurannya}

\section{Variabel dependen}

Financial leverage diukur dengan rasio nilai buku total hutang terhadap jumlah nilai buku total hutang ditambah nilai pasar total ekuitas (Lee-Hsien et al, 2015; Fan, et al, 2012). Nilai pasar total ekuitas diperoleh dari perkalian antara harga saham per lembar dengan jumlah saham beredar.

\section{Variabel independen}

Untuk mengukur specificity and opacity level of asset, penulis menggunakan tiga buah ukuran. Pertama, rasio beban internal R\&D terhadap total penjualan. Kedua, rasio biaya pemasaran terhadap penjualan bersih. Ketiga, rasio biaya gaji dengan total biaya operasional. Dalam riset ini penulis menggunakan rasio biaya gaji pegawai terhadap total biaya operasional perusahaan yang lebih akurat dalam mengukur tingkat keunikan asset perusahaan dibandingkan dengan alat ukur yang telah digunakan oleh para peneliti sebelum ini (misalnya De Vita, et al, (2011) dan Shou, et al (2013) yang tidak menskalakan (adjusted) biaya pegawai terhadap total biaya operasional perusahaan.

\section{Variabel kontrol}

Penulis menggunakan empat variable kontrol untuk mendapatkan hasil uji yang lebih tajam (robust) antara struktur modal perusahaan dengan kepemilikan asset spesifik. Pertama, pertumbuhan penjualan sebagai proxy peluang pertumbuhan. Kedua, profitabilitas perusahaan yang dihitung dengan rasio EBIT terhadap nilai penjualan. Ketiga, rasio non-debt tax shields terhadap total asset. Keempat, probabilita kebangkrutan perusahaan.

Tabel 2. Variabel Penelitian

\begin{tabular}{|c|c|c|}
\hline Variabel & Keterangan & Referensi \\
\hline \multicolumn{3}{|l|}{ Variabel Bebas } \\
\hline Leverage & $\begin{array}{l}\text { Rasio nilai buku total hutang terhadap jumlah nilai } \\
\text { buku total hutang ditambah nilai pasar total } \\
\text { ekuitas }\end{array}$ & $\begin{array}{l}\text { Lee-Hsien et al. (2015); } \\
\text { Fan, et al.(2012) }\end{array}$ \\
\hline \multicolumn{3}{|l|}{ Variabel Terikat } \\
\hline \multirow[t]{3}{*}{$\begin{array}{l}\text { Proxy Asset Specificity } \\
\text { and Opacity }\end{array}$} & $\begin{array}{l}\text { 1. Rasio beban internal R\&D terhadap total } \\
\text { penjualan. }\end{array}$ & De Vita et al (2011) \\
\hline & $\begin{array}{l}\text { 2. Rasio biaya pemasaran terhadap penjualan } \\
\text { bersih. }\end{array}$ & $\begin{array}{l}\text { Shou, et al } \\
\text { (2013); Mingyue (2011) }\end{array}$ \\
\hline & $\begin{array}{l}\text { 3. Rasio biaya gaji dengan total biaya } \\
\text { operasional. }\end{array}$ & Mingyue (2011) \\
\hline \multicolumn{3}{|l|}{ Variabel Kontrol } \\
\hline Peluang Petumbuhan & Pertumbuhan Penjualan & Williamson,(2010) \\
\hline Non Debt Tax Shield & Rasio Non Debt Tax Shield terhadap Total Asset & Blouin, et al (2010) \\
\hline Probabilita & Rasio Volatilitas Laba Usaha terhadap Jumlah & Ciliberto dan Schenone \\
\hline Kebangkrutan & Laba (Rugi) Usaha dan Nilai Ekuitas & $(2012)$ \\
\hline Tingkat Profitabilitas & Rasio Laba Usaha Terhadap Total Asset Bersih & $\begin{array}{l}\text { Modifikasi dari Vilasuso } \\
\text { dan Minkler (2001) dan } \\
\text { Lee-Hsien, et al (2015) }\end{array}$ \\
\hline
\end{tabular}


Beberapa peneliti seperti Vilasuso dan Minkler (2001) dan Lee-Hsien, et al (2015) menggunakan ROE sebagai ukuran profitabilitas, namun indikator ini dapat bias karena laba bersih telah dikurangi besarnya bunga pinjaman yang merupakan output dari kebijakan pendanaan itu sendiri. Profitabilitas perusahaan lebih tepat diukur dengan laba operasi dan perlu disesuaikan dengan besarnya asset perusahaan. Oleh karenanya penulis menggunakan laba usaha dibagi dengan total asset bersih. Untuk mengukur non-debt tax shields (NDT) penelitian ini mengikuti metode Blouin, et al, (2010) yang dihitung dengan formula:

$\operatorname{Tax}=\tau(\mathrm{OI}-\mathrm{i}-\mathrm{NDT})(1)$

Tax adalah Pajak Penghasilan badan perusahaan, adalah tingkat pajak perusahaan, adalah bunga hutang, adalah pendapatan usaha, NDT adalah non debt tax shields.

Untuk menghitung probabilita bangkrut, penelitian ini menggunakan metode Ciliberto dan Schenone (2012) yang menggunakan formula berikut ini:

$$
\text { Probability of default }(\mathrm{PD})=\frac{\text { Standardized } . \sigma_{\mathrm{OI}}}{\mathrm{E}(\mathrm{OI}+\mathrm{EQ})}
$$

D atau Probability of default adalah peluang terjadinya kebangkrutan, Standardized $\sigma_{\mathrm{O}}$ adalah standar deviasi pendapatan usaha distandarkan dengan nilai asset perusahaan, adalah pendapatan usaha, dan EQ adalah nilai buku ekuitas.

Logika dari model probabilitas kebangkrutan di atas adalah semakin besar dispersi atau naik-turunnya pendapatan usaha perusahaan semakin dibutuhkan buffer yang besar untuk mencegah perusahaan mengalami kesulitan keuangan. Buffer tersebut dalam bentuk besarnya pendapatan usaha pada suatu periode dan modal disetor perusahaan yang tercermin dari nilai buku ekuitas perusahaan.

Untuk melihat perbedaaan antara perusahaan BUMN dan non BUMN akan dibedakan dengan sebuah variable dummy. Demikian juga dengan perusahaan-perusahaan yang berada dalam satu grup usaha atau holding tertentu yang kebijakan modalnya sangat dipengaruhi oleh keputusan holdingnya. Perusahaan seperti ini juga akan dilihat pengaruhnya dengan diberi sebuah variable dummy juga.

\section{Model Penelitian}

Model penelitian adalah model panel data random effect sebagai berikut:

$$
\begin{aligned}
L E V_{i, t} \alpha_{i}=+ & \beta_{1} R D_{i, t}+\beta_{2} M K T_{i, t}+\beta_{3} \text { Wages }_{i, t}+\beta_{4} \text { Growth }_{i, t}+\beta_{5} N D T_{i, t}+\beta_{6} \text { Profit }+\beta_{7} \text { Default } \beta_{8} \text { BUMN } \\
& +\beta_{9} \text { Grup }+\varepsilon_{i, t}
\end{aligned}
$$

LEV adalah tingkat leverage perusahaan, RD adalah biaya R\&D/Total Asset, MKT adalah Marketing Cost/Total Asset, Wages adalah Biaya Gaji/Total Asset, Growth adalah pertumbuhan penjualan, NDT adalah Non Debt Tax Shields, Profit = EBIT/Total Asset, Default adalah probabilita kepailitan. BUMN adalah dummy variable, variabel BUMN $=1$ jika perusahaan adalah BUMN, dan 0 jika non BUMN, Grup adalah dummy variable, variabel Grup $=1$ jika perusahaan bergabung dalam grup usaha, dan 0 jika tidak bergabung dalam sebuah grup usaha.

Random effect model digunakan karena diasumsikan terdapat perubahan karakteristik individu dalam periode yang diamati, misalnya karena adanya perubahan kualitas asset yang spesifik yang dimiliki setiap perusahaan atau karena perubahan kualitas sumber daya manusia sebagai akibat proses training dan coaching serta program Research and Development (R\&D) internal yang dijalankan oleh perusahaan. Random effect model dapat menangkap perubahan antar individu dan antar waktu secara lebih baik dari pada model data panel lainnya yaitu Fixed effect model yang mengasumsikan seluruh karakteristik individu bersifat fixed selama periode observasi (Baltagi, 2008).

Menurut literature ekonometrika data panel yang terbaru seperti Wooldridge (2012), pemilihan model panel antara fixed effect dan random effect berasal dari asumsi atas unobserved 
effect misalnya budaya kerja yang mempengaruhi produktivitas dan efisiensi, atau strategi pemasaran yang menciptakan loyalitas konsumen yang sering tidak berwujud yang tidak dimasukkan ke dalam model. Apabila unobserved effect tidak berubah antar individu atau kelompok yang ada dalam data, atau berubah antar waktu maka model panel yang dipilih adalah fixed effect. Sementara apabila unobserved effect berubah antar individu atau antar waktu maka random effect yang dipilih. Pendekatan lebih praktis diambil berdasarkan pernyataan Gujarati dan Porter (2008) bahwa jika jumlah cross section banyak dan time series relative sedikit maka random effect lebih tepat untuk digunakan dari pada fixed effect. Taylor (1980) membuktikan jika $\mathrm{T}>3$ dan N-K > 9 dimana K adalah jumlah regresor maka Random Effect Model sebaiknya digunakan. Pada penelitian ini $\mathrm{T}=14$ dan $\mathrm{N}=169, \mathrm{~K}=10$, jadi pemilihan Random Effect memiliki alasan lebih kuat. Uji Hausman sebagai uji formal pemilihan model data panel antara fixed effect dan random effect, yang akan dijelaskan pada sub Analisis dan Pembahasan setelah ini, memperkuat pilihan atas model random effect.

Untuk mengestimasi persamaan Model penelitian di atas, penulis menggunakan metode estimasi data panel Generalized Method of Moment (GMM) random effect. Metode ini dipilih karena GMM random effect dapat mengatasi masalah heteroskedastisitas yang ada pada data perbankan Chakraborty (2010). Selanjutnya, secara parsial masing-masing variabel bebas akan diuji apakah berpengaruh secara signifikan terhadap variabel tidak bebas. Selain itu, pada model tersebut, nilai $R$-Squared akan menjelaskan seberapa besar informasi pada variabel bebas dapat menjelaskan variabel tidak bebas.

Estimasi dengan OLS akan menghasilkan koefisien dan standar error yang bias apabila ada perbedaan signifikan $\alpha_{i}$ antar perusahaan (firm-specific effects), dimana $\alpha_{i}$ bersifat tidak dapat diukur (unobservable) dan kovarians antara variabel-variabel penjelas dengan $\alpha_{i}$ tidak sama dengan nol (Hsiao, 1985). Dalam kondisi seperti kepemilikan asset spesifik, asumsi ini sangat besar peluangnya untuk terpenuhi (Chakraaborty, 2010). Apabila residual $\varepsilon$ tidak berkorelasi serial, metode estimasi GMM dari Arellano and Bond (1991) adalah metode (Wooldridge, 2012).

\section{Analisis dan Pembahasan}

Data deskriptif dari seluruh variable dapat diihat pada Tabel 3. Rata-rata rasio biaya R\&D terhadap total biaya relative masih sangat rendah. Rasio biaya pemasaran dan biaya gaji memiliki standar deviasi yang cukup besar, yang menunjukkan adanya perbedaan antar perusahaan yang relative besar. Variable kontrol pertumbuhan penjualan, profitabilitas dan non debt tax shield menunjukkan perbedaan yang cukup besar pula karena ada sebagian perusahaan yang mengalami kerugian pada periode yang diobservasi dan memiliki non debt tax shield. Probabilita kebangkrutan sebagian perusahaan menunjukkan posisi yang rawan karena fluktuasi laba usaha tidak dapat ditutupi dari ekuitas perusahaan dan rata-rata laba usaha yang biasa diperoleh perusahaan.

Tabel 3. Data Deskriptif

\begin{tabular}{lccccc}
\hline \multicolumn{1}{c}{ Variabel } & Mean & Median & Maximum & Minimum & Std. Dev. \\
\hline R\&D & 0.04854 & 0.0267 & 0.0856 & 0.0000 & 0.0490 \\
MKTCOST & 0.1191 & 0.1485 & 0.2863 & 0.0330 & 0.1495 \\
WAGES & 0.0842 & 0.0891 & 0.1065 & 0.0593 & 0.1862 \\
SALESGROWTH & 0.1459 & 0.1591 & 0.2548 & -0.1433 & 0.5406 \\
EBIT/SALES & 0.15660 & 0.1014 & -0.4609 & -0.5502 & 0.8521 \\
NDT & 0.1708 & 0.1654 & 0.2347 & 0.00617 & 0.2197 \\
DEFAULPROB & 0.3834 & 0.5746 & 0.9912 & 0.0814 & 0.9320 \\
\hline
\end{tabular}

Hasil uji Hausman yang ada pada Tabel 4 menunjukkan model panel data Random Effect yang lebih tepat digunakan dari pada model Fixed Effect. 
Table 4. Uji Hausman

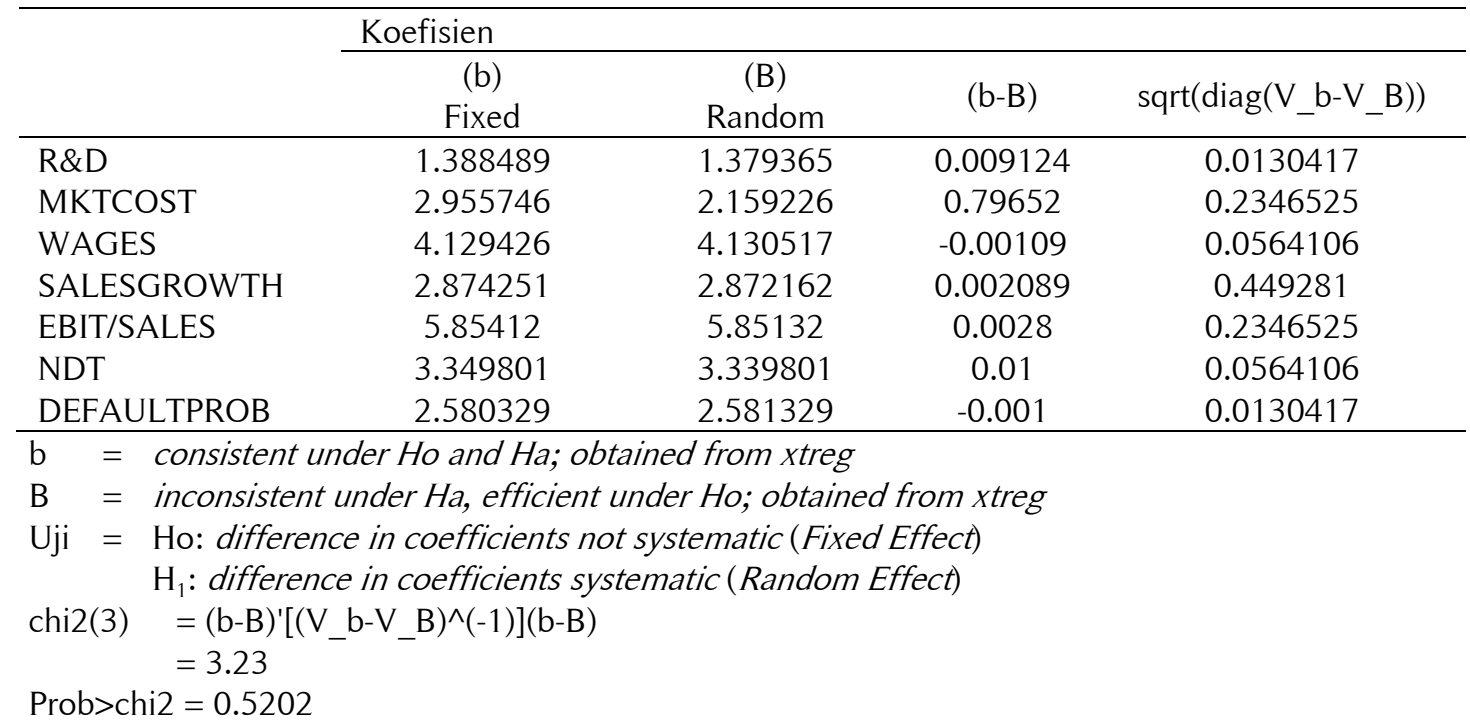

Tabel 5. Hasil Estimasi Model Penelitian

\begin{tabular}{|c|c|c|c|c|}
\hline Koefisien & Model 1 & Model 2 & Model 3 & Model 4 \\
\hline$R \& D$ & $\begin{array}{c}21,2 \\
(0,38)\end{array}$ & $(7,21)$ & $(7,96)$ & $\begin{array}{c}1,37 \\
(0,98)\end{array}$ \\
\hline MKTCOST & $(3,400)$ & $\begin{array}{c}2,13 \\
(1,21)\end{array}$ & $(4,12)$ & $\begin{array}{c}2,15 \\
(1,15)\end{array}$ \\
\hline WAGES & $(49,57$ & $(52,31)$ & $\begin{array}{c}-4,27 * * \\
(4,46)\end{array}$ & $\begin{array}{c}-4,13 * * \\
(3,16)\end{array}$ \\
\hline SALESGROWTH & $\begin{array}{c}2,87 * * \\
(2,98) \\
-5,87 * *\end{array}$ & $\begin{array}{c}2,85^{* *} \\
2,97)(3,01) \\
-5,84 * *\end{array}$ & $\begin{array}{c}2,86^{* *} \\
2,98)(1,53) \\
-5,83^{* *}\end{array}$ & $\begin{array}{c}2,87^{* *} \\
2,91)(6,01) \\
-5,85^{* *}\end{array}$ \\
\hline EBIT/SALES & $\begin{array}{c}(2,97) \\
-3.34 * *\end{array}$ & $\begin{array}{c}2,95)(1,32) \\
-3.35^{* *}\end{array}$ & $\begin{array}{c}2,97)(5,35) \\
-3.36^{* *}\end{array}$ & $\begin{array}{c}2,93)(5,43) \\
-3.33^{*}\end{array}$ \\
\hline NDT & $(3,23)$ & $3,32)(2,13)$ & $3,27)(1,11)$ & $3,21)(0,23)$ \\
\hline ADEFAULPROB & $\begin{array}{c}-2,56 * * \\
(3,01)\end{array}$ & $\begin{array}{c}-2,57^{* *} \\
3,21)(1,09)\end{array}$ & $\begin{array}{c}-2,59 * * \\
3,11)(1,97)\end{array}$ & $\begin{array}{c}-2,58^{* *} \\
3,11)(2,61)\end{array}$ \\
\hline BUMN & 0 & 0 & $\begin{array}{l}1,87 * * \\
(3,98)\end{array}$ & $\begin{array}{l}1,85 * * \\
(3,97)\end{array}$ \\
\hline Group & 9 & 9 & $\begin{array}{r}2,87 * * \\
(2,97)\end{array}$ & $\begin{array}{r}2,84 * * \\
(2,95)\end{array}$ \\
\hline Error Term Correlation $1^{\text {st }}$ order & 0,01 & 0,008 & 0,007 & 0,06 \\
\hline Error Term Correlation $2^{\text {nd }}$ order & 0,002 & 0,001 & 0,003 & 0,006 \\
\hline Sargan Test & $\begin{array}{c}133,72 \\
(77)\end{array}$ & $\begin{array}{c}137,89 \\
(77)\end{array}$ & $\begin{array}{c}133,91 \\
(77)\end{array}$ & $\begin{array}{c}131,77 \\
(77)\end{array}$ \\
\hline
\end{tabular}

Keterangan: Standard error ada di dalam kurung

*koefisien signifikan pada level of error $10 \%$

$* *$ koefisien signifikan pada level of error $5 \%$

$* * *$ koefisien signifikan pada level of error $1 \%$

Model empirik yang digunakan adalah model data panel random effect dengan metode estimasi GMM. Efisiensi dari GMM estimator tergantung pada terpenuhinnya asumsi lagged values of the dependent variable dan variable penjelas lainnya adalah instrument yang valid dan error terms dari model tidak menunjukkan adanya serial correlation. Untuk menguji hal ini Arellano and Bond (1991) mengajukan tiga test. Tes pertama menguji tidak ada first order serial 
autocorrelation pada error term dengan menggunakan autocorrelation function dan korelogram. Jika hypothesis nol tidak adal serial correlation terpenuhi, test statistic terdistribusi sebagai sebuah standard normal. Tes kedua menguji tidak ada second order serial autocorrelation pada error term dengan menggunakan autocorrelation function dan korelogram. Test ketiga adalah Sargan test yang menguji validitas model dan over-identifying restrictions dan ketika $\chi^{2}$ dibawah batas hipotesis nol validitas instrument terdistribusi asymptotically distributed. Hasil olah data dapat dilihat pada Tabel 5 .

Model penelitian diestimasi sebanyak empat kali. Model 4 di dalam Tabel 5 menunjukkan model yang berisi seluruh variable penjelas. Model 1, Model 2, dan Model 3 adalah model yang mengestimasi hubungan parsial antara struktur modal perusahaan dengan sebuah variable proxy asset yang spesifik, yang secara berurutan biaya $R \& D$, biaya pemasaran, dan biaya gaji. Uji Sargan Test untuk keempat model yang diestimasi menunjukkan validitas model yang baik. Sementara uji autocorrelation first order dan second order dari error term menunjukkan korelasi yang sangat rendah sehingga dapat dikategorikan tidak terdapat serial correlation pada error term. Ketiga uji ini menunjukkan estimator yang dihasilkan metode eesimasi GMM tidak bias dan efisien.

Variabel yang mengukur indikasi kepemilikan asset spesifik yaitu biaya R\&D dan biaya pemasaran tidak punya pengaruh signifikan terhadap tingkat leverage. Temuan empirik ini bertentangan dengan rerangka konseptual yang ada pada literatur manajemen strategik dan hasi uji empiric dari Chakraborty (2013), Chakraborty (2010), dan Vilasuso dan Minkler (2001) seperti yang telah dibahas di atas. Hanya variabel WAGES yaitu rasio antara jumlah gaji dengan nilai penjualan yang signifikan. Hasil uji konsisten baik pada uji parsial maupun secara bersamaan. Hal ini menunjukkan adanya kondisi empirik perusahaan Indonesia yang unik dan berbeda dengan teori yang telah berkembang di literature ilmiah yang ada. Kondisi lingkungan bisnis Indonesia yang relative sangat jarang melakukan riset dan pengembangan seperti yang dapat dilihat pada laporan World Develoment Indicators yang dikeluarkan oleh World Bank yang perbandingannya dengan beberapa negara sebagiannya dapat dilihat pada Tabel 1. Temuan penelitian ini berbeda dengan temuan Chakraborty (2010) yang mengobservasi perusahaanperusahaan India yang juga rata-rata memiliki biaya $R \& D$ yang rendah, namun memang rata-rata biaya R\&D perusahaan India tidak serendah perusahaan Indonesia. Hal ini sangat besar kemungkinan disebabkan oleh kondisi perusahaan di Indonesia dan praktek bisnis yang mereka lakukan seperti yang didapati juga pada beberapa perusahaan India oleh Chakraborty (2010) atau praktek akuntansi yang konservatif yang dijalankan rata-rata perusahaan Indonesia sesuai PSAK Indonesia. Efek praktek akuntansi yang konservatif terhadap struktur modal perusahaan ditemukan juga oleh Yan (2012) pada perusahaan China.

Perusahaan Indonesia secara umum belum melakukan akumulasi asset spesifik secara internal. Mereka lebih banyak mengimpor langsung teknologi dan asset-asset yang mereka butuhkan. Selain itu produk utama kebanyakan perusahaan Indonesia lebih banyak berupa komoditas bahan mentah yang nilai tambah karena proses dan teknologi masih realtif sangat rendah. Aktivitas Researh \& Development perusahaan Indonesia masih relatif minim, kalaupun ada tidak persisten muncul setiap tahun. Kespesifikan asset perusahaan Indonesia tidak dapat ditangkap menggunakan metode pengukuran yang telah berkembang di dalam literature ilmiah yang ada. Hal yang mirip dihadapi oleh Chakraborty (2010) dengan data perusahaan India dan Yan (2012) dengan data perusahaan China.

Hasil uji penelitian ini yang menunjukkan biaya gaji sangat signifikan mempengaruhi leverage perusahaan memberikan indikasi perusahaan Indonesia baru sampai pada tahap menjaga kerahasiaan kepemilikan dan proses akumulasi internal asset yang spesifik dengan memberikan gaji yang cukup tinggi kepada karyawannya sehingga loyalitas karyawan dapat dijaga dan kebocoran informasi kepada kompetitor dapat dicegah. Hal yang hampir mirip ditemukan oleh Chakraborty (2010) di India, namun selain biaya gaji, biaya R\&D juga signifikan 
pengaruhnya terhadap struktur modal perusahaan India. Jadi di India, kepemilikan asset spesifik dapat diukur dengan proxy biaya gaji dan biaya R\&D. Pada kasus perusahaan Indonesia yang hanya biaya gaji saja yang signifikan, kesimpulan perlu diambil secara lebih hati-hati seperti yang ditunjukkan oleh Yan (2012).

Menurut Yan (2012) apabila dari ketiga variabel proxy kepemilikan asset hanya biaya gaji saja yang signifikan mempengaruhi struktur modal maka leverage yang rendah bisa jadi tidak disebabkan oleh kepemilikan asset spesifik namun lebih karena struktur biaya perusahaan. Struktur biaya perusahaan yang padat karya dan rendah tingkat otomatisasi dan mekanisasi proses produksinya akan memiliki rasio biaya gaji terhadap total biaya operasi yang relatif besar. Indikasi dari dugaan Yan (2012) ini pada konteks perusahaan Indonesia cukup kuat sehingga perlu dipikirkan variabel proxy atas kepemilikan asset spesifik yang lebih robust pada konteks rendahnya rata-rata biaya $R \& D$ perusahaan dan struktur biaya yang capital intensive.

Hasil uji empirik yang berbeda dengan literatur teoretis yang ada seperti yang dapat dilihat pada Tabel 5 di atas dapat disebabkan juga oleh prosedur akuntansi yang berlaku di Indonesia yang mendorong perusahaan menjadi lebih pragmatis dalam memandang kegiatan riset. Kegiatan research dan development belum cukup berkembang (Lihat Tabel 1) di perusahaan-perusahaan Indonesia, bukan saja disebabkan karena lemahnya kemampuan teknologi dan daya inovasi karyawan, namun juga disebabkan oleh prinsip akuntansi yang berlaku di Indonesia yang masih konservatif dalam pencatatan biaya riset dan pengembangan. Pencatatan biaya riset dan pengembangan secara akuntansi kurang menguntungkan bagi perusahaan karena harus diakui sebagai biaya pada tahun berjalan sementara manfaat dari riset dan pengembangan produk baru dapat dirasakan beberapa tahun kemudian. Perusahaanperusahaan Indonesia menjadi sangat pragmatis dan hanya menjadi konsumen hasil penelitian dan pengembangan dari perusahaan-perusahaan asing. Temuan ini seperti yang ditemukan oleh Lev et al (2005) di beberapa negara yang menganut prinsip konservatif dalam pencatatan biaya riset dan pengembangan. Wang, et al (2012) menunjukkan bahwa terdapat hubungan yang kuat antara prinsip akuntansi yang berlaku disuatu negara dengan perilaku perusahaan dalam mengakumulasi asset-asset yang spesifik.

Biaya pemasaran juga patut dicurigai akurasi pencatatannya secara riil karena pada prakteknya biaya-biaya lobby dan biaya entertainment dalam upaya memperoleh suatu proyek seringkali digabung dalam pos biaya pemasaran. Padahal praktek bisnis yang masih cukup banyak dijalankan di lingkungan usaha yang tinggi tingkat korupsinya seperti di Indonesia sangat besar mempengaruhi nilai biaya lobby dan entertainment tersebut. Akurasi pengukuran ini yang patut diduga menyebabkan uji empirik pada perusahaan-perusahaan Indonesia menunjukkan tidak signifikannya biaya pemasaran sebagai proxy variable tingkat akumulasi asset yang spesifik dalam mempengaruhi besarnya leverage perusahaan.

Semua variabel kontrol signifikan. Peluang pertumbuhan yang didekati dari pertumbuhan penjualan signifikan dengan tanda positif yang berarti semakin tinggi peluang pertumbuhhan perusahaan, struktur modal lebih didominasi oleh hutang. Hal yang sangat logis karena kredit perbankan lebih mudah disalurkan oleh banker kepada perusahaan yang dinilai memiliki prospek pertumbuhan yang bagus. Temuan ini ditemukan oleh semua uji sebeum ini seperti Yan (2012), Chakraborty (2010), Wang et al (2012) dan Vilasuso dan Minkler (2001)

Variabel control lain yang signifikan adalah besarnya profitabilitas perusahaan yang secara signifikan mempengaruhi tingkat leverage perusahaan. Tanda yang negatif menunjukkan leverage perusahaan semakin rendah dengan semakin tingginya laba usaha. Temuan ini sesuai dengan hipotesis pecking order theory dimana perusahaan cenderung menggunakan dana internal terlebih dahulu sebelum menggunakan hutang. Signifikannya Non Debt-Tax shield (NDT) semakin memperkuat indikasi ini, dimana semakin besarnya free cash flow perusahaan yang ditunjukkan dari besarnya NDT mendorong perusahaan menunda pengeluaran hutang sehingga leverage semakin rendah. Hal ini sesuai dengan rerangka konseptual dari pecking order 
theory. Temuan penelitian ini mirip dengan temuan Chakraborty (2010) di India namun berbeda dengan temuan Wang et al (2012) dan Yan (2012) di China. Di China, hubungan NDT dengan leverage bersifat positif. Perbedaan temuan di Indonesia dan di India dengan temuan di China dapat diduga karena kebutuhan investasi yang jauh lebih besar pada perusahaan-perusahaan China yang banyak berorientasi ekspor dan memiliki kapasitas produksi raksasa.

Signifikannya variabel default probability sudah sesuai dengan hipotesis yang dibangun yaitu perusahaan dengan default probability yang tinggi akan menghindari pembiayaan melalui hutang karena interest rate spread yang harus ditanggung perusahaan dengan risiko kebangkrutan yang besar akan semakin tinggi. Perusahaan yang memiliki default probability yang tinggi, akan cenderung menggunakan pendanaan internal atau dengan cara mengeluarkan saham. Investor di bursa saham relatif lebih toleran terhadap probability of default sebuah perusahaan selama probability tersebut dikompensasi dalam volatilitas return yang tinggi pula. Temuan ini sama pada semua uji empirik yang ada sebelum ini seperti Chakraborty (2010), Yan (2012), dan Platt dan Platt (2002).

Dummy variabel Grup terbukti signifikan dan positif yang menunjukkan bahwa posisi perusahaan yang berada dalam grup usaha tertentu atau dalam suatu konglomerasi akan cenderung menggunakan pembiayaan dari hutang. Temuan yang sama ditemukan Chakraborty (2013). Seperti yang dinyatakan oleh Chakraborty (2013), efek afiliasi terhadap grup usaha tertentu terhadap struktur modal perusahaan perlu dikaji lebih lanjut dengan memperhatikan jenis konglomerasi setiap grup usaha. Menurut Chakraboty (2013), jenis grup usaha yang bersifat focused business group yang bergerak pada bisnis tertentu yang saling berkaitan dan memanfaatkan competitive advantage yang telah terbentuk dan berangkat dari core competence yang sama akan memiliki strategi pendanaan yang berbeda dengan grup usaha yang bersifat multi bisnis dan diversified conglomeration.

Sementara itu dummy variabel BUMN tidak signifikan, yang berarti strategi pembiayaan BUMN tidak ada perbedaaan signifikan dengan perusahaan non BUMN. Perusahaan BUMN Indonesia yang sudah tercatat sahamnya di bursa efek dikelola oleh para profesional dan dalam penentuan jumlah leverage tidak banyak dipengaruhi oleh kebijakan pemerintah sebagai pemegang saham. Namun adanya penanaman modal negara (PMN) pada beberapa BUMN yang dilakukan oleh rezim pemerintahan terakhir dan rencana membentuk holding BUMN diduga dapat menyebabkan perubahan yang cukup signifikan

\section{Simpulan}

Strategi pendanaan perusahaan terbuka di Indonesia tidak terbukti dipengaruhi secara signifikan oleh karakteristik asset yang spesifik dan opaque. Leverage perusahaan Indonesia tidak pengaruhi oleh variabel-variabel yang menjadi ukuran adanya upaya akumulasi asset yang spesifik dan opaque. Temuan ini makin memperkuat dugaan bahwa perusahaan Indonesia belum secara terencana membangun kekauatan bersaing dengan menguasai asset-asset yang spesifik demi menciptakan distinctive competence. Hanya satu variabel yang digunakan sebagai indikator adanya upaya akumulasi asset yang spesifik yaitu WAGES atau gaji karyawan. Perusahaan Indonesia baru sampai pada tahap menjaga kerahasiaan kepemilikan dan proses akumulasi internal asset yang spesifik dengan memberikan gaji yang cukup tinggi kepada karyawannya sehingga loyalitas karyawan dapat dijaga dan kebocoran informasi kepada kompetitor dapat dicegah.

Tidak signifikannya pengaruh karakteristik asset terhadap keputusan struktur modal perusahaan diduga karena prinsip dan prosedur akuntansi Indonesia yang belum sepenuhnya mendukung aktivitas riset dan pengembangan internal perusahaan. Pengukuran biaya riset dan pengembangan menjadi bias. Hal ini ditemukan pula oleh Lev. et al (2005) di negara-negara yang menganut prinsip akuntansi yang mirip. 
Untuk mempertajam hasil penelitian, perlu diteliti lebih lanjut modifikasi metode pengukuran spesifikasi asset dan asset opacity dengan mengidentikasi terlebih dahulu praktekpraktek pencatatan biaya riset dan pengembangan yang jamak dilakukan oleh perusahaanperusahaan Indonesia untuk menghindari bias pencatatan R\&D seperti yang ditunjukkan oleh Lev et al (2005).

\section{Daftar Pustaka}

Aggha, S., Alrubaiee, L., \& Jamhour, M. (2012) Effect of Core Competence on Competitive Advantage and Organizational Performance, International Journal of Business and Management, 1 (7) 213-230.

Altman, E., \& Sabato, G. (2007). Modelling Credit Risk for SMEs: Evidence from the U.S. Market, Abacus Journal of Accounting, Finance, dan Business Studies, 43(3), 332-357.

Arellano, M. \&, Bond, S., (1991). Some tests of specification for panel data: Monte Carlo evidence and an application to employment equations. Review of Economics Studies. 58, 277-297.

Baltagi, B. (2008), Econometric Analysis of Panel Data, Wiley and Sons.

Benmelech, E.(2009), Asset Salability and Debt Maturity: Evidence from Nineteenth Century American Railroads, Review of Financial Studies, 22, 1545-1583.

Blouin, J., Core, J., \& Guay, W. (2010). Have the Tax Benefits of Debt been Overestimated?, Journal of Financial Economics, 7(1),378-397.

Chakraborty, I. (2013). Does capital structure depend on group affiliation? An analysis of Indian firms, Journal of Policy Modeling, 35(1), 110-112.

Chakraborty, I. (2010). Capital structure in an emerging stock market: The case of India, Research in International Business and Finance 37(3), 295-314.

Ciliberto, F., \& Schenone, C., (2012). Are the bankrupt skies the friendliest? Journal of Corporate Finance, 18 (5), 1217-1231.

De Vita, G., Tekaya, A., \& Wang, C.(2011). The Many Faces of Asset Specificity: A Critical Review of Key Theoretical Perspectives, International Journal of Management Reviews 13 (4),329-348.

Du, J., \& Girma, S. (2012), Firm Size, Source of Finance, and Growth - Evidence from China, International Journal of the Economics of Business, 19(3), 653-661.

Grant, R. 1991. The resource-based theory of competitive advantage: implications for strategy formulation. California Management Review, 114-135.

Grice, J., \& Ingram, R. (2001), Tests of the generalizability of Altman's bankruptcy prediction model, Journal of Business Research.

Gujarati, D. \& Porter, W (2008) Basic Econometrics, McGraw Hill 5 th edition, p 651.

Henard, D., \& McFadyen, M. (2012). Resource Dedication and New Product Performance: A Resource-Based View, Journal of Product Innovation Management 29 (2), 193-204.

Hsiao, C., (1985). Benefits and limitations of panel data. Econometrics Review. 46 (4), 12511271.

James, C., \& Kizilaslan, A.(2014). Asset Specificity, Industry-Driven Recovery Risk, and Loan Pricing, Journal of Financial and Quantitative Analysis, 49 (03), 599-631. 
Khare, N., \& Leiblein, M (2014). Asset Specificity and the Governance Forms: Do dyad perspective and endogeneity matter? Academy of Management Journal (5), 287-296.

Lee-Hsien, P., Chien-Ting, L., Shih-Cheng, L., \& Kung-Cheng, H. (2015). Information rating and Capital structure. Journal of Corporate Finance, 31, 17-32.

Lev, B., Sarath, B., \& Sougiannis, T. (2005). R\&D Reporting Biases and Their Consequences, Contemporary Accounting Research 22(4), 489-498.

Mingyue, F. (2011), Asset Specificity, Financing Capacity and Companies M\&A: Evidence from Chinese A-share Industrial Listed Companies, Journal of Financial Research.

Platt, H., \& Platt, M.(2002). Predicting corporate financial distress: reflections on choice-based sample bias, Journal of Economics and Finance 5 (3), 192-220.

Rajan, R., \& Zingales, L.(1995). What do we know about capital structure? Some evidence from international data. Journal of Finance 50 (1), 1421-1460.

Shou, Z., Yang, L., Zhang, Q., \& Su, C.(2013). Market munificence and inter-firm information sharing: The moderating effect of specific assets, Journal of Business Research 7 (2), 130120.

Taylor, W E. (1980) Small Sample considerations in the estimation from Panel Data, Journal of Econometrics, vol 13, p 203-223.

Vicente-Lorente, J., (2001). Specificity and opacity as resource-based determinants of capital structure: evidence for Spanish manufacturing firms, Strategic Management Journal, 22(2), 157-177.

Williamson, D.(2010). Financial-market contracting. In: Klein, P. \& Sykuta, M. (Eds.). The Elgar companion to transaction cost economics. Cheltenham: Elgar Publishing Ltda, p. 244260.

Wang,H., Li, Q .,\& Wang, Y (2013), Asset Specificity and the Financial Accounting Behaviors: A Literature Review, Accounting and Economics Research 2(1).

World Bank, (2015). World Development Indicator, World Data Bank. World Bank, New York

Vilasuso, J. \& Minkler, A. (2001). Agency Cost, Asset Specificity, and the Capital Structure of the Firm, Journal of Economic Behavior and Organization, 44, 55-69.

Wooldridge, J (2012) Econometric Analysis of Cross Section and Panel Data, Massachussetts Institute of Technology, p $251-252$.

Specificity and Accounting Conservatism-the Mediating Effect of Capital Structure, East China Economic Management, 12(2), 112-134. 